\title{
SOSIALISASI PENCEGAHAN PENYEBARAN HOAX DALAM PEMBELAJARAN IPS DENGAN APLIKASI HBT V2
}

\author{
Bintang Muhammad Sahara Efendi, Nadia Mustikarani, Setyawan Triaditama, Tsamrotul \\ Muqtashida, Agung Wiradimadja*
}

agung.wiradimadja.fis@um.ac.id

Prodi Pendidikan IPS, Fakultas IImu Sosial, Universitas Negeri Malang

Diterima 25 November 2020, dipublikasikan 30 April 2021

\begin{abstract}
Abstrak
Perkembangan teknologi informasi yang semakin canggih dapat mempengaruhi kehidupan masyarakat. Masyarakat mengalami berbagai perubahan yang terjadi dalam kehidupan mereka, salah satunya semakin maraknya penyebaran hoax. Pembelajaran IPS di tingkat SMP memanfaatkan berbagai sumber informasi seperti berita di media massa elektronik. Jika sumber pembelajaran yang digunakan terindikasi berita hoax akan berakibat pada pemberian informasi yang keliru terhadap para siswa. Berdasarkan hal tersebut, dapat dilakukannya pencegahan berita hoax menggunakan aplikasi HBT (Hoax Buster Tools) V2 yang dapat memberikan kemudahan dalam memverifikasi berita yang ada fakta atau malah sebaliknya. Tim Pengabdian kepada masyarakat melakukan kegiatan sosialisasi pencegahan penyebaran hoax melalui media sosial WhatsApp Group. Kegiatan sosialisasi ini bertujuan memberikan edukasi kepada masyarakat dalam upaya pencegahan berita hoax melalui aplikasi HBT V2. Setelah kegiatan sosialisasi berakhir, tim pengabdian melakukan wawancara kepada para peserta berkaitan dengan kegiatan yang telah dilaksanakan. Data pendapat yang diperoleh dari peserta sosialisasi pencegahan penyebaran hoax melalui aplikasi HBT V2 sebanyak 43 orang yang terdiri dari kalangan mahasiswa, dosen, guru IPS, dan masyarakat umum. Adapun data diperoleh melalui wawancara, studi literatur, dan dokumentasi. Hasil survei menunjukkan bahwa sebanyak 46,8 persen peserta berpendapat bahwa kegiatan sosialisasi yang dilakukan oleh tim pengabdian kepada masyarakat dinilai sangat baik. Sebanyak 59,6 persen peserta menyatakan bahwa sosialisasi ini bermanfaat untuk mencegah penyebaran hoax dalam diri sendiri. Sebanyak 46,8 persen peserta menyatakan aplikasi HBT V2 telah efektif dalam mencegah penyebaran hoax. Sebanyak 89,4 persen peserta memilih akan terus memanfaatkan aplikasi HBT V2 dalam pencegahan penyebaran hoax.
\end{abstract}

Kata Kunci: Pencegahan Hoax, HBT V2, Pembelajaran IPS

\section{PENDAHULUAN}

Pesatnya perkembangan teknologi informasi membuat banyak perubahan yang terjadi dalam kehidupan. Salah satunya ialah dalam bidang teknologi informasi, dimana semakin banyak aplikasi sosial media yang memudahkan kita dalam memperoleh informasi dan berkomunikasi. Perubahanperubahan yang terjadi ini banyak memberikan dampak positif namun, juga memberikan dampak negatif. Salah satu dampak negatif yang diberikan ialah adanya berita hoax. Hoax sudah menjadi seperti makanan masyarakat Indonesia setiap harinya. Secara tidak langsung hoax memberikan dampak negatif yang cukup besar bagi kehidupan kita. Dampak negatif itu muncul semakin besar dibarengi dengan kebiasaan masyarakat Indonesia yang malas membaca. Oleh karena itu, membuat masyarakat Indonesia senang berbicara tanpa data yang valid sehingga peluang penyebaran hoax semakin besar. Mereka dengan mudah menelan segala informasi yang didapatkan tanpa meneliti kembali kevalidan informasi tersebut dan dengan mudah menyebarkan ke orang terdekat mereka. Menurut Latupeirissa (2021), pelaku penyebaran hoax dapat berasal dari seluruh lapisan masyarakat tak terkecuali dari kalangan pelajar sekalipun.

Berdasarkan data APJII diperoleh pada tahun 2018 konsumen internet di Indonesia sejumlah 171,17 juta pengguna dari 264,16 juta jiwa. Bahkan angka pengguna ini meningkat dari tahun sebelumnya sebesar $10,12 \%$. Menurut Siddiq (2020), masyarakat Indonesia aktif berselancar selama 1,5 jam dalam sehari di dunia maya. Sedangkan, berdasarkan data yang dirilis oleh Kominfo (dalam 
Yuliani, 2017) melalui portal resminya, kurang lebih ada sekitar 800.000 ribu situs internet penyebar hoax. Berdasarkan kedua data ini, dapat kita lihat bahwa sangat riskan sekali jika para pengguna internet tidak memiliki bekal yang cukup dalam mengoperasikan internet tersebut. Hal ini pula membuat dengan mudahnya sebuah berita atau informasi menjadi viral termasuk hoax. Dimana hoax akan merugikan banyak pihak karena bisa mempengaruhi pembacanya.

Pembelajaran IPS di sekolah memanfaatkan berbagai sumber seperti buku, majalah dan media massa baik elektronik maupun cetak sebagai sumber belajar. Sumber belajar elektronik seperti berita online menjadi sumber belajar yang paling mudah diakses dengan berkembang pesatnya teknologi informasi. Para siswa SMP di kota besar di Indonesia saat ini umumnya sudah memiliki gadget berupa smartphone. Agar kegiatan pembelajaran IPS dapat berjalan maksimal dalam hal literasi, guru sering mendorong para siswanya agar memanfaatkan gadget yang mereka miliki untuk browsing literatur yang ada di Internet sebagai sumber belajar. Proses pencarian tersebut ditujukan untuk melengkapi materimateri pembelajaran IPS yang akan diberikan kepada siswa. Melalui perkembangan teknologi informasi jaringan internet, para siswa dapat dengan mudah dan cepat dalam memperoleh informasi dan berkomunikasi tanpa harus terikat oleh ruang dan waktu. Sehingga kegiatan pembelajaran berjalan lebih efektif dan efisien dari adanya internet sebagai sumber belajar (Sasmita, 2020). Apabila hoax telah menyebar hingga masuk pada ranah informasi pembelajaran IPS, maka akan menyebabkan kerancuan dan ketidakvalidan informasi.

Sudah ada banyak solusi yang diberikan guna meminimalisir penyebaran hoax. Mulai dari pemerintah, aparat penegak hukum hingga masyarakat itu sendiri. Namun, tetap saja hoax dengan pesatnya berkembang dan merasuk dalam kehidupan setiap orang. Beragam solusi yang telah diberikan salah satunya yang dilakukan oleh kepolisian di mana ada tiga bagian pokok yang dilakukan untuk menanggulangi penyebaran berita hoax (Monica, 2018). Ketiga bagian itu ialah pre-emtif, preventif dan represif. Pre-emtif ialah tindakan yang dilakukan dengan menanamkan nilai dan norma baik sehingga bisa mencegah seseorang melakukan tindakan ini. Preventif merupakan tindakan lanjutan dari pre-emtif di mana Satuan Tugas Cyber Patrol dibentuk oleh kepolisisan untuk mengawasi teknologi informasi seperti media sosial. Terakhir represif ialah tindakan yang dilakukan setelah terjadi tindak pidana kejahatan berupa penyebaran hoax dengan memberikan hukuman. Selain upaya yang dilakukan oleh kepolisian, masyarakat utamanya komunitas-komunitas juga sering melakukan sosialisasi tentang hoax ini dan cara penanganannya. Meskipun, sudah banyak cara dilakukan tetap saja penyebaran hoax terjadi di internet.

Oleh karena itu, tim pengabdian melakukan sosialisasi terhadap masyarakat sebagai upaya penanggulangan penyebaran hoax dengan menggunakan sebuah aplikasi pintar pencegah penyebaran hoax. Aplikasi tersebut ialah HBT V2 atau Hoax Buster Tools V2. Kegiatan sosialisasi ini dilaksanakan secara daring melalui media sosial WhatsApp Group yang dilanjutkan dengan kegiatan diskusi antar presenter dan para peserta sosialisasi dalam sebuah diskusi interaktif bertajuk sosialisasi yang membahas mengenai hoax secara detail dan cara penanggulangannya menggunakan aplikasi HBT V2.

Tujuan dari penulisan artikel ini ialah sebagai bentuk edukasi kepada masyarakat akan cara penanggulangan penyebaran hoax menggunakan sebuah aplikasi modern, HBT V2. Mengingat hoax sangat berpengaruh dalam kehidupan masyarakat sehingga perlu adanya tindakan untuk mengantisipasinya.

\section{METODE}

Adapun metode pelaksanaan program sosialisasi pencegahan penyebaran hoax dalam pembelajaran IPS dengan aplikasi HBT V2 sebagai berikut:

\section{Tahap Perencanaan}

Tahap perencanaan dimulai dengan dibentuknyaa tim pengabdian masyarakat yang terdiri dari empat orang. Kemudian dilanjutkan dengan penyusunan dan pengajuan proposal. Adapula susunan kegiatan pada tahap ini yang dimulai dari bulan Agustus hingga bulan September 2020. Pertama, pembentukan tim pengabdian. Kedua, analisis permasalahan sosial dan melakukan pengamatan secara daring. Ketiga, penyusunan proposal pengabdian. 


\section{Tahap Persiapan}

Tahap persiapan dilakukan dalam satu bulan penuh pada bulan Oktober. Pertama, pembuatan WhatsApp Group pelaksanaan sosialisasi dan pembuatan video tutorial mengunduh dan mengoperasikan aplikasi HBT V2. Kedua, mencari pemateri, membuatan tautan pendaftaran peserta, dan membuat tautan angket evaluasi. Ketiga, pembuatan dan penyebaran poster kegiatan serta gladi resik pelaksanaan kegiatan sosialisasi.

\section{Tahap Pelaksanaan}

Tahap pelaksanaan dilakukan selama kurang lebih sekitar tiga jam dimulai pukul $08.30-11.30$ WIB di Hari Sabtu, 7 November 2020. Pada tahap ini memuat pelaksanaan pengabdian dalam bentuk sosialisasi secara daring dengan menggunakan media WhatsApp Group. Sosialisasi daring ini dilakukan melalui pemaparan materi kemudian disusul dengan tanya jawab antara peserta dengan pemateri. Sebelum acara sosialisasi diakhiri, tim pengabdian melakukan pengumpulan data kepada para peserta dengan memberikan tautan presensi peserta dan angket evaluasi sosialisasi. Peserta yang berpartisipasi dalam acara ini berjumlah 43 orang yang terdiri dari 1 dosen dan 42 mahasiswa. Dalam tahap pelaksanaan terdiri dari dua materi yang disampaikan. Pertama, materi terkait pencegahan penyebaran hoax dalam pembelajaran IPS. Kedua, materi terkait pengenalan dan pengoperasian aplikasi HBT V2 dalam mencegah penyebaran hoax.

\section{Tahap Evaluasi}

Tahap evaluasi dilaksanakan selama enam minggu. Dimana minggu pertama hingga minggu kedua yaitu evaluasi pelaksanaan dan analisis data. Sedangkan, minggu ketiga hingga keenam yaitu melakukan penyusunan luaran dan penyusunan laporan akhir kegiatan. Adapun penilaian dari peserta mengenai sosialisasi ini rata-rata sudah cukup baik dan penggunaan aplikasi HBT V2 dalam mencegah penyebaran sangat efektif digunakan karena banyak fitur yang tersedia dalam aplikasi sehingga memberikan manfaat dan memudahkan pengoperasian aplikasi HBT V2 bagi pengguna.

\section{HASIL DAN PEMBAHASAN \\ Deskripsi Kegiatan}

Kegiatan ini merupakan pengabdian masyarakat dengan bentuk sosialisasi yang dilakukan menggunakan media digital. Menurut KBBI Online, sosialisasi ialah upaya memasyarakatkan sesuatu hal untuk diketahui, dikenal, dipahami, dihayati oleh masyarakat. Tujuan dilakukannya seminar kepada masyarakat ini untuk mengedukasi masyarakat agar menjadi lebih bijak dalam menyikapi maraknya penyebaran berita hoax. Lalu memberikan solusi dengan adanya aplikasi anti hoax yaitu HBT (Hoax Buster Tools) sebagai tindakan preventif dalam kasus penyebaran hoax. Setelah kegiatan sosialisasi dilaksanakan, akan tumbuh kepedulian dan kesadaran para peserta akan bahaya penyebaran hoax (Sutantohadi, 2018). Sehingga aplikasi HBT akan terus digunakan secara berkelanjutan dan disebarluaskan sebagai bukti kepedulian akan pencegahan penyebaran hoax.

Metode pelaksanaannya berbentuk sosialisasi daring dengan menggunakan WhatsApp Group sebagai media yang digunakan. Kegiatan sosialisasi daring ini dilaksanakan kurang lebih selama tiga jam. Dalam pelaksanaanya terdiri dari dua materi yang disampaikan. Pertama, materi mengenai pencegahan penyebaran hoax dalam pembelajaran IPS. Kedua, materi mengenai pengenalan dan pengoperasian aplikasi HBT V2 dalam mencegah penyebaran hoax. Setelah itu, peserta diberikan beberapa berita untuk mencoba mengidentifikasi, apakah berita tersebut hoax atau tidak. Lalu, tim menganalisis dan mengevaluasi apakah aplikasi HBT sukses atau tidak dalam menangkal persebaran hoax.

\section{Deskripsi Materi Kegiatan Mengenai Hoax}

Hoax diterjemahkan menjadi hoaks menurut KBBI Online yang artinya informasi bohong. Sedangkan dalam Kamus Istilah Jurnalistik, berita bohong atau libel diartikan sebagai berita yang belum tentu kebenarannya dan dapat berdampak pada pencemaran nama baik. Menurut Rianto (2017) pengertian hoax ialah suatu muslihat untuk mengakali pengguna media sosial dengan mengklaim suatu barang atau kejadian dengan label lain yang tidak sesuai kenyataan, padahal pelaku sejatinya sudah mengetahui pemberitaan tersebut hanyalah palsu belaka. Saat ini orang lebih cenderung mudah 
mempercayai informasi yang beredar jika hal itu sesuai dengan pemikiran pribadinya (Respati, 2017). Sehingga dapat disimpulkan bahwa hoax merupakan suatu rekayasa yang bahkan seringkali tidak masuk akal namun digunakan untuk mengelabui orang lain di media sosial agar ikut memercayai berita tersebut.

Dalam penyebaran hoax, tidak serta merta datang begitu saja. Tentu saja pasti ada faktor yang menjadi penyebab munculnya hoax di tengah tengah masyarakat. Menurut Rosmalinda (dalam Marwan, 2016) berdasarkan penyebab munculnya hoax ada tiga. Pertama, komunikasi yang semakin modern mempermudah penyebaran informasi di antara masyarakat. Kedua, mudahnya mempercayai informasi yang diterima dan menyebarkannya tanpa memverifikasi kebenaran dari informasi yang diterima. Ketiga, minat baca masyarakat yang kurang dengan mengandalkan daya ingat saja ketika membaca suatu berita. Hoax memiliki tiga ciri khusus yaitu pertama, dapat menimbulkan kecemasan, kebencian, hingga permusuhan. Kedua, ketidakjelasan sumber berita. Ketiga, bermuatan fanatisme untuk menyembunyikan fakta dan data yang ada. Ketiga ciri tersebut adalah ciri ciri yang paling mencolok dan dapat diidentifikasi oleh masyarakat secara teliti.

Sebenarnya banyak sekali motif yang menjadi tujuan pelaku dalam penyebaran hoax. Namun, pada umumnya hoax disebarkan dengan tujuan having fun, lelucon, menjatuhkan pesaing (black campaign) atau mengajak pembaca agar melakukan ajaran agama yang sebenarnya tidak memiliki dalil yang kuat (Mustika, 2018). Rianto (2017) dalam artikelnya menyebutkan jenis-jenis dari hoax, antara lain:

1. Fake News

Sebuah berita yang bertujuan untuk memanipulasi berita yang asli dengan menambahkan informasi yang tidak benar adanya.

2. Clickbait

Laman jebakan yang dapat ditemukan di sebuah situs yang mengandung konten yang sebenarnya namun memiliki judul yang berlebihan/memprovokasi serta gambar yang dapat memikat pembaca.

3. Confirmation bias

Keinginan untuk menggambarkan suatu kejadian dengan mencari informasi yang sesuai opini penulis serta menolak apabila bertentangan dengan opini tersebut.

4. Misinformation

Suatu informasi atau berita yang tidak akurat dan biasa ditujukan untul menipu orang lain.

5. Satire

Suatu komentar yang bernada humor atau berita yang dibesar-besarkan dengan tujuan menanggapi kejadian yang up-to-date di masyarakat.

6. Post-truth

Memiliki arti pasca kebenaran. Suatu berita atau informasi yang menciptakan opini publik yang di mana emosi penulis lebih besar daripada fakta yang ada.

7. Propaganda

Suatu usaha dalam memengaruhi pandangan publik dengan cara menyebarkan sebuah informasi baik itu fakta ataupun setengah kebenaran. 


\section{Hoax dalam Pembelajaran IPS}

Permendiknas Nomor 22 Tahun 2006 menyatakan beberapa tujuan dari pembelajaran IPS agar peserta didik dapat memiliki empat kemampuan dasar. Pertama, dapat mengetahui dan memahami konsep yang berhubungan dalam kehidupan sehari-hari di lingkungan masyarakat. Kedua dapat memiliki keinginan untuk berkomitmen dan sadar terhadap nilai-nilai sosial dan kemanusiaan. Ketiga, dapat berpikir dengan logis dan kritis, inkuiri, keingintahuan yang tinggi, serta keterampilan dalam berkehidupan sosial. Keempat, dapat memiliki kemampuan dalam komunikasi, kerjasama, kompetisi di berbagai tingkat.

Menurut Septanto (2018), dampak dari berita hoax sangatlah besar di masyarakat karena dapat merusak kerukunan dan harmoni sosial serta dapat memecah belah persatuan yang telah dibangun oleh masyarakat itu sendiri. Pengaruh dari penyebaran hoax di media sosial berdampak besar yang menimbulkan kecurigaan, kebencian, bahkan rasa sentimen terhadap orang yang berbeda agama pada berita hoax yang terkandung unsur SARA. Sedangkan menurut Aditiawarman (dalam Dulkiah, 2020: 7) menyebutkan dampak dari persebaran hoax cenderung percaya tanpa melakukan verifikasi atau uji keaslian data, lebih buruknya cenderung untuk menyebarkannya kepada khalayak ramai tanpa memverifikasinya terlebih dahulu. Selain itu, hoax dalam politik juga menimbulkan sebuah polarisasi pada masyarakat, seperti penggunaan istilah cebong dan kampret (Dulkiah, 2020).

Dampak negatif dari penyebaran hoax dalam pembelajaran IPS ialah cenderung menyerang keadaan psikologis. Pertama, menimbulkan rasa khawatir atau cemas guru dan peserta didik, sehingga pembelajaran IPS tidak berjalan efektif. Kedua, menyulut peserta didik atau guru untuk berpikir negatif. Ketiga, menyulut emosi dalam pembelajaran IPS. Keempat, pengetahuan yang salah diterima dalam pembelajaran IPS. Informasi berupa pengetahuan yang menyangkut mata pelajaran IPS juga menjadi ancaman. Beberapa kali penulis menjumpai informasi yang menyangkut hal tersebut disampaikan guru kepada muridnya dalam pembelajaran IPS. Peserta didik masih banyak belum bisa memikirkan apakah hal itu benar atau bukan. mereka langsung mempercayai. Hal ini yang menjadi tidak baik karena informasi yang salah itu dibenarkan dan dapat tersebar luas, yang akhirnya mengakibatkan kemunduran ilmu pengetahuan.

\section{Pemanfaatan Aplikasi HBT V2}

Banyaknya dampak negatif yang ditimbulkan mengakibatkan berdirinya sebuah komunitas anti hoax yaitu MAFINDO (Masyarakat Anti Fitnah Indonesia) (Septanto, 2018). Komunitas ini juga membuat sebuah aplikasi yaitu Hoax Buster Tools V2 (HBT V2) yang rilis pada tanggal 3 September 2019. Tercatat sudah sebanyak 1000 orang yang telah mendownload aplikasi ini di Play Store. Aplikasi HBT V2 dapat digunakan untuk memeriksa suatu artikel berita yang diterbitkan oleh media resmi dan terdaftar di IWARI (Ikatan Wartawan RI) dan dewan pers. Aplikasi ini tidak hanya sekedar memverifikasi sebuah tulisan berita saja, tapi juga dapat berbentuk gambar, video dan juga menyelidiki akun-akun media sosial. Tentu dengan kehadiran Aplikasi HBT V2 ini, sangat bermanfaat bagi masyarakat karena mempunyai wadah untuk mengecek dan memvalidasi berita-berita yang beredar. Diharapkan dengan adanya aplikasi HBT V2 ini, masyarakat Indonesia tidak lagi termakan oleh unsur-unsur fitnah yang bisa menjadikan bangsa kita terpecah belah. Di dalam aplikasi ini terdapat berbagai macam kategori atau fitur-fitur yang dapat digunakan, diantaranya adalah: Pencarian, Verifikasi Gambar, Verifikasi Video, Analisa Media Sosial, Pengecekan Orang, Turn Back Hoax.id, dan Lapor Hoax. 


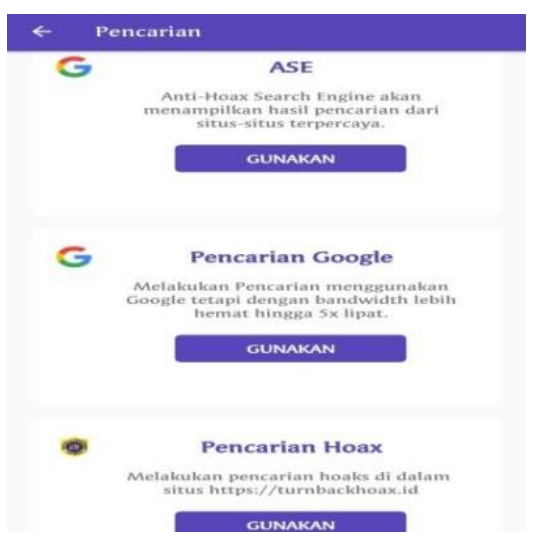

Gambar 1. Fitur Pencarian

Kategori pencarian ialah fitur yang dapat digunakan untuk melacak berita-berita tertulis dari artikel-artikel yang beredar. Jika memasukkan kata kunci berita yang ingin dicari, pengguna akan disuguhkan dengan artikel-artikel yang telah akurat dan menunjukkan apakah berita yang dicari itu Hoax atau benar. Pengguna bisa melakukan pencarian dengan menggunakan Anti-Hoax Search Engine (ASE) atau langsung pada pencarian Google. Pada kategori ini, Pengguna juga bisa memanfaatkan Fitur Pencarian Hoax untuk mengetahui artikel berita yang telah terverifikasi hanya Hoax.

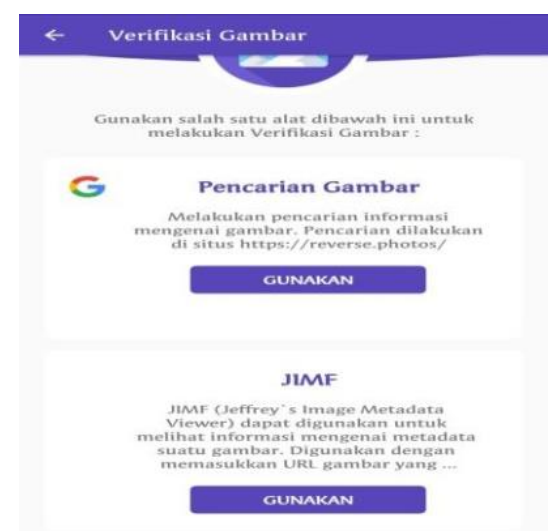

Gambar 2. Fitur Verifikasi Gambar

Dalam Kategori Verifikasi Gambar ini, pengguna dapat mengupload contoh gambar yang akan dicari beritanya. Pengguna dapat menggunakan Pencarian gambar dengan memanfaatkan Fitur Pencarian Gambar Google dan Juga JIMF. Namun lebih disarankan untuk menggunakan fitur pencarian aplikasi Google. Setelah mengupload gambar dari galeri masing-masing, pengguna akan disuguhkan dengan berita-berita yang terkait dengan gambar tersebut pada laman Google.

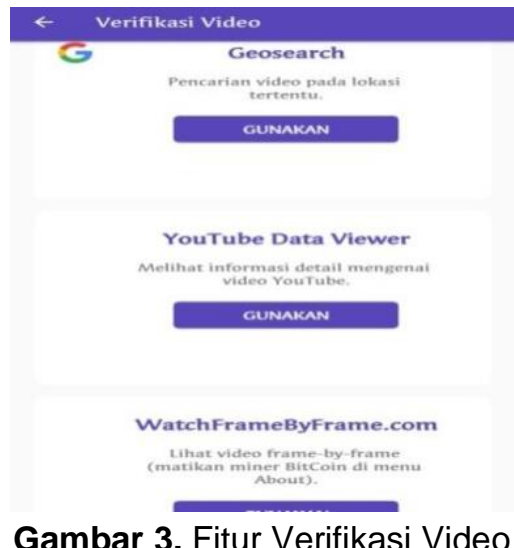


Cara penggunaan Kategori Verifikasi Video ini, pengguna dapat memanfaatkan Fitur Gosearch untuk pencarian video pada lokasi tertentu, Fitur Youtube Data Viewer untuk melihat info mengenai video Youtube dan Fitur Watch Frame by frame.

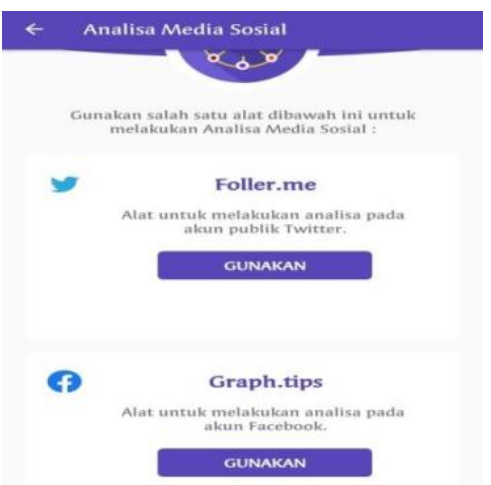

Gambar 4. Fitur Analisa Media Sosial

Pada Kategori Analisa Media Sosial, pengguna dapat mengecek akun-akun media sosial di Facebook dan Twitter. Pengguna dapat memeriksa akun tersebut milik seorang tokoh publik atau akun resmi suatu organisasi/pemerintah.

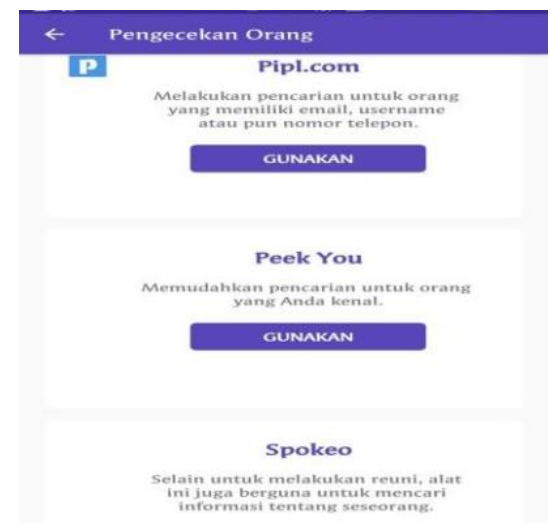

Gambar 5. Fitur Pengecekan Orang

Kategori Pengecekan Orang hingga saat ini masih merupakan fitur yang berbayar. Sehingga tidak dapat diakses dengan gratis. Kategori ini dapat digunakan untuk mengecek Track Record seseorang apakah memiliki catatan kriminal atau sebagainya

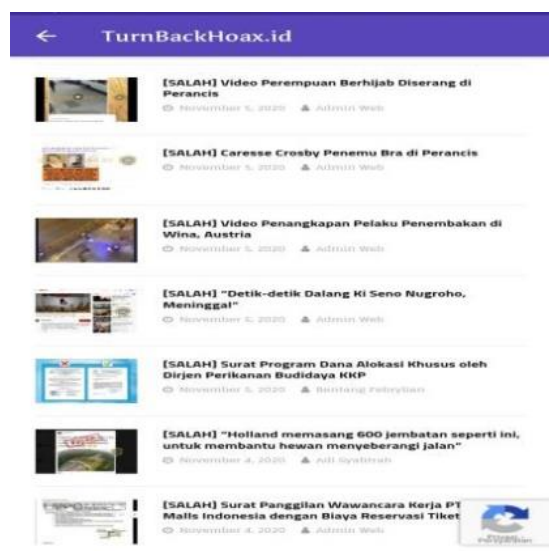

Gambar 6. Kategori Turn Back Hoax.id

Pada kategori Turn Back Hoax.id Pengguna dapat menemukan dan membaca ratusan kumpulan-kumpulan berita yang telah terverifikasi hoax oleh aplikasi HBT V2 ini. Berita-berita yang disajikan merupakan berita acak dari berbagai tema. Dan hebatnya lagi, dipilihan fitur ini dijelaskan juga alasan mengapa berita tersebut hoax dan bukti referensinya. 


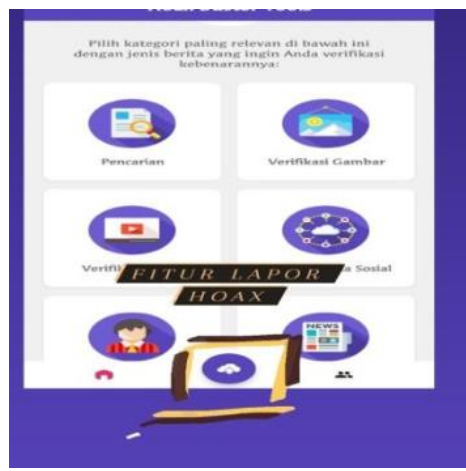

Gambar 7. Fitur Lapor Hoax

Fitur ini, mewadahi Pengguna untuk melaporkan berita-berita hoax yang ditemukan. Pengguna hanya tinggal mengikuti panduan-panduan yang sudah tertera di dalamnya. Panduan yang tertera ialah dengan cara mengisi nama dan email serta judul laporan yang akan diajukan. Setelah itu, pengguna dapat menyalin teks hoax dengan tidak merubah kata-katanya serta dapat memasukkan pesan/alasan yang ingin sampaikan. Dan yang paling terpenting ialah unggah bukti screenshoot berita yang telah didapatkan agar dapat dijadikan bukti valid tentang laporan yang diajukan.

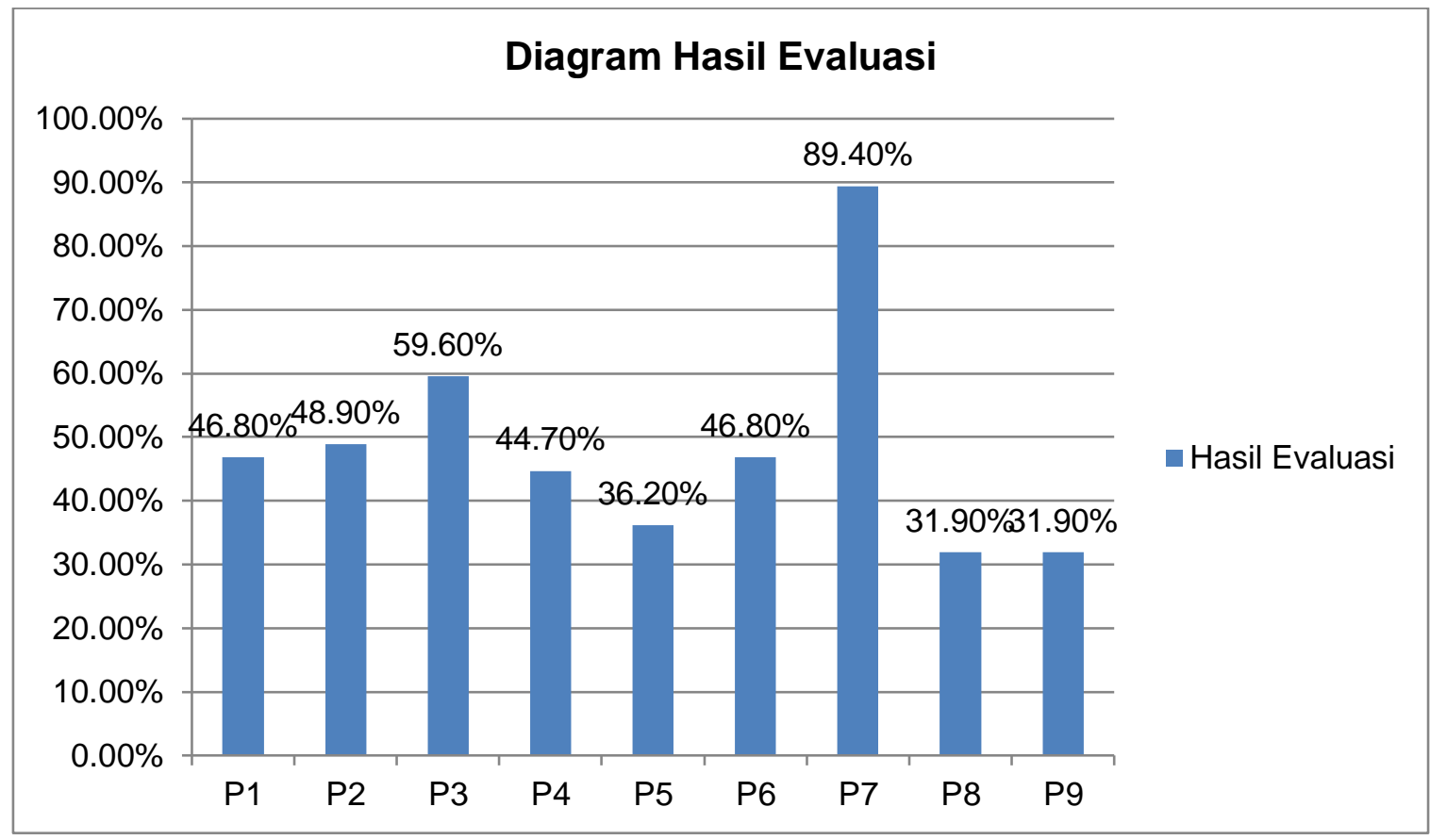

Gambar 8. Diagram Hasil Evaluasi

Dari diagram hasil evaluasi diatas diperoleh bahwa sebanyak $46,8 \%$ informan menilai sangat baik terhadap sosialisasi yang dilaksanakan. Sebanyak 48,9\% informan menyatakan telah memahami mengenai sosialisasi yang diadakan. Sebanyak $59,6 \%$ informan menyatakan bahwa sosialisasi ini sangat bermanfaat untuk mencegah pengaruh penyebaran hoax dalam diri peserta. Sebanyak 44,7\% informan telah memahami apa itu HBT V2. Sebanyak 36,2\% informan menyatakan telah cukup memahami pengoperasian HBT V2. Sebanyak 46,8\% informan menyatakan Aplikasi HBT V2 telah efektif dalam mencegah penyebaran hoax. Menurut informan, Aplikasi HBT V2 ini dapat dikatakan efektif karena cara pengunduhannya yang mudah serta fitur-fitur didalamnya telah mencakup semua hal yang diperlukan untuk mengetahui kebenaran berita yang beredar.

Tercatat sebanyak 89,4\% informan memilih akan terus menggunakan Aplikasi HBT V2 dalam mencegah penyebaran hoax. Alasannya karena, aplikasi ini berguna dalam menemukan bukti-bukti konkret tentang berita yang beredar, dapat membantu masyarakat agar tidak mudah terprovokasi apabila terdapat berita yang masih simpang siur. Terlebih, sebagian besar informan yang merupakan seorang mahasiswa yang berpendidikan sangat membutuhkan aplikasi ini untuk diperkenalkan dan 
diajarkan kepada orang-orang disekitarnya. Sebanyak 31,9\% informan memilih Fitur Pencarian Google sebagai fitur yang paling efektif dalam mencegah penyebaran hoax. Alasannya karena, cara pengoperasiannya yang mudah yakni dengan hanya mengetikkan kata atau kalimat maka otomatis akan muncul beberapa hoax terkait. Terlebih berita-berita yang ditampilkan telah terverifikasi dan memiliki bukti referensinya. Untuk fitur yang paling sulit pengoperasiannya, sebanyak $31,9 \%$ informan memilih Fitur Turn Back Hoax.id. alasannya karena, masih kurangnya pemahaman serta dinilai terlalu rumit dalam pengoperasiannya. Menurut informan, perlu ketelitian dalam pencarian berita ketika menggunakan aplikasi ini.

Saat mengajukan pertanyaan terkait dampak yang terjadi dari penyebaran hoax terhadap Pembelajaran IPS, kebanyakan informan berpendapat bahwa akan menyebabkan munculnya pengaruh negatif dalam proses Pembelajaran IPS. Penyebaran hoax dalam bidang pendidikan khususnya Pembelajaran IPS akan menyebabkan terganggunya pemahaman pola pikir siswa dan guru. Sehingga ilmu yang diterima, tidak valid akan kebenarannya. Terjadinya kesalahpahaman dalam proses pembelajaran pun akan rentan terjadi. Terlebih jika sudah tidak adanya kepercayaan antara pemahaman siswa dengan guru atau sebaliknya.

\section{KESIMPULAN}

Kegiatan sosialisasi yang dilaksanakan melalui WhatsApp Group dengan dua materi yang disampaikan. Pertama, mengenai pencegahan penyebaran hoax dalam pembelajaran IPS. Kedua, mengenai pengenalan dan pengoperasian aplikasi HBT (Hoax Buster Tools) V2. Tujuan dilaksanakannya sosialisasi ini untuk mengedukasi masyarakat agar berlaku bijak dalam menanggapi berita yang belum terbukti jelas maupun nyata atau yang disebut juga dengan hoax. Dengan adanya aplikasi HBT V2 dapat memberikan solusi untuk mencegah penyebaran hoax tersebut. Beberapa informan pun akan terus menggunakan aplikasi HBT V2 dalam pencegahan penyebaran hoax. Alasannya, karena aplikasi ini berguna dalam menemukan bukti-bukti konkret tentang berita yang beredar, dapat membantu masyarakat agar tidak mudah terprovokasi akan berita yang masih simpang siur.

\section{DAFTAR PUSTAKA}

APJII. 2018. Survei APJII yang Ditunggu-tunggu, Penetrasi Internet Indonesia 2018. (Online) (https://apjii.or.id/content/read/104/418/BULETIN-APJII-EDISI-40---Mei-2019). Diakses pada 21 November 2020.

Departemen IImu Komunikasi Fakultas IImu-IImu Sosial Universitas Indonesia. 1985. Kamus Istilah Jurnalistik. Jakarta: Pusat Pembinaan dan Pengembangan Bahasa.

Dulkiah, M., \& Setia, P. 2020. Pola Penyebaran Hoaks pada Kalangan Mahasiswa Perguruan Tinggi Islam di Kota Bandung. Jurnal SMART (Studi Masyarakat,Religi, dan Tradisi), 6(2), 1-15.

KBBI Daring. 2016. (Online). (https://kbbi.kemdikbud.go.id/entri/hoaks) Diakses pada 21 November 2020

KBBI Daring. 2016. (Online). (https://kbbi.kemdikbud.go.id/entri/sosialisasi) Diakses pada 21 November 2020

Latupeirissa, J. E., Pasalbessy, J. D., Leasa, E. Z., \& Tuhumury, C. 2021. Penyebaran Berita Bohong (HOAX) Pada Masa Pandemi Covid-19 dan Upaya Penanggulangannya di Provinsi Maluku. JURNAL BELO, 6(2), 179-194.

Marwan, M. R., \& Ahyad, A. 2016. Analisis Penyebaran Berita Hoax di Indonesia. Jurusan IImu Komunikasi, Fakultas IImu Komunikasi Universitas Gunadarma.

Mustika, R. 2018. ETIKA BERKOMUNIKASI DI MEDIA ONLINE DALAM MENANGKAL HOAX. Diakom : Jurnal Media dan Komunikasi, 1(2), 43-50. https://doi.org/10.17933/diakom.v1i2.30

Monica, D. R. 2018. Upaya Kepolisian dalam Penanggulangan Tindak Pidana Penyebaran Hoax. Jurnal Poenale, 5(2), 13.

Permendiknas Nomor 22 Tahun 2006 Tentang Standar Isi untuk Satuan Pendidikan Dasar dan Menengah. 
Rahadi, D. R. 2017. Perilaku Pengguna dan Informasi Hoax di Media Sosial. Jurnal Manajemen dan Kewirausahaan, 5(1), 58-70.

Respati, S. 2017. Mengapa Banyak Orang Mudah Percaya Berita Hoax?. (Online) (http://nasional.kompas.com/read/2017/01/23/18181951/mengapa.banyak.orang.mudah.percay a.berita.hoax) Diakses pada 21 November 2020

Sasmita, R. S. 2020. Pemanfaatan Internet Sebagai Sumber Belajar. Jurnal Pendidikan dan Konseling (JPDK), 2(1), 117-121.

Septanto, H. 2018. Pengaruh Hoax dan Ujaran Kebencian Sebuah Cyber Crime dengan Teknologi Sederhana di Kehidupan Sosial Masyarakat. Jurnal Kalbiscientia: Jurnal Sains dan Teknologi, 5(2), 157-162.

Shiddiq, S. 2020. Pengaruh Media Sosial Facebook Dalam Penyebaran Hoax Dan Dampaknya Terhadap Kecemasan Masyarakat (Studi Terhadap Masyarakat Di Kota Yogyakarta) (Doctoral dissertation, Universitas Mercu Buana Yogyakarta).

Sutantohadi, A. 2018. Bahaya Berita Hoax dan Ujaran Kebencian pada Media Sosial Terhadap Toleransi Bermasyarakat. DIKEMAS (Jurnal Pengabdian Kepada Masyarakat), 1(1).

Yuliani, A. 2017. Ada 800.000 Situs Penyebar Hoax di Indonesia. (Online). (https://kominfo.go.id/content/detail/12008/ada-800000-situs-penyebar-hoax-di indonesia/0/sorotan_media\#: :text=Sekitar\%20250\%20elemen\%20masyarakat\%20Kota,Gerak an\%20Masyarakat\%20NTT\%20Melawan\%20Hoax\%22). Diakses pada 21 November 2020. 